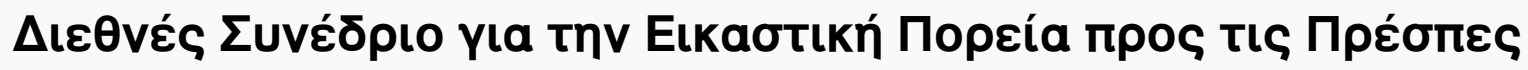

Tóp. 4 (2015)

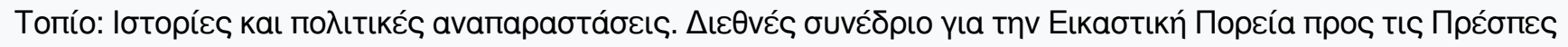

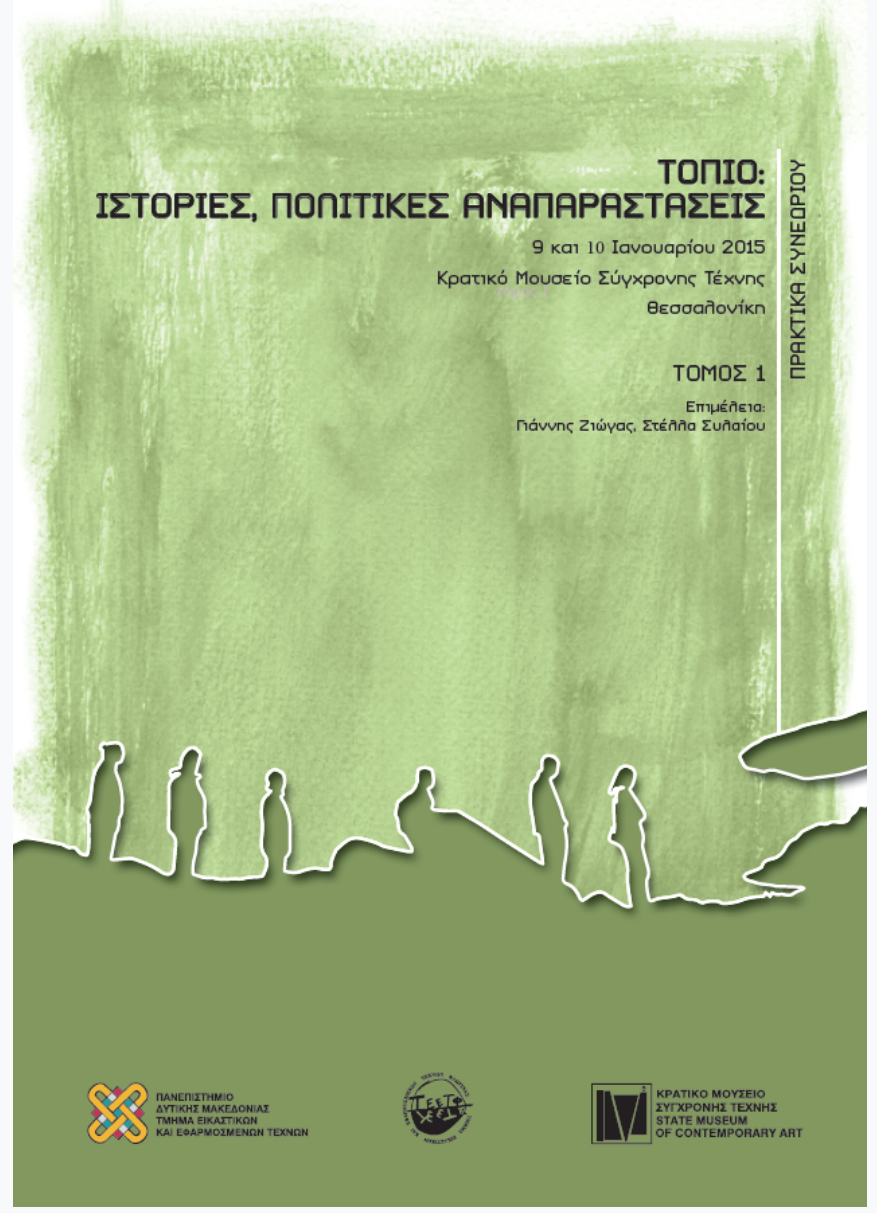

\section{Revisiting the Walk}

Erika Osborne

doi: $10.12681 /$ visualmarch.3067 


\section{Revisiting the Walk}

Erika Osborne

Assistant Professor, Department of Art, Colorado State University, Fort Collins, Colorado

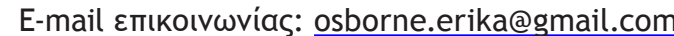

\section{(}

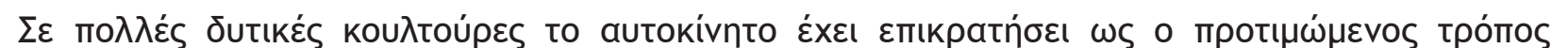

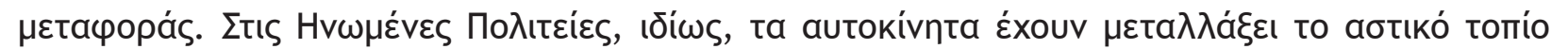

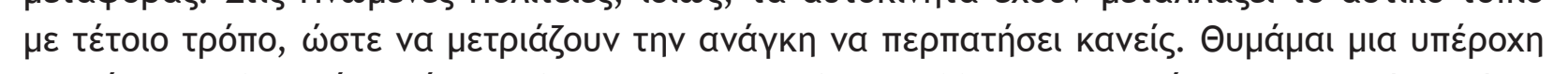

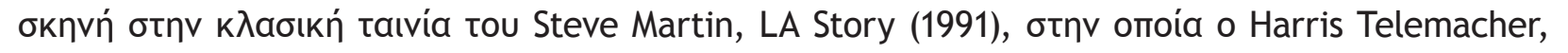

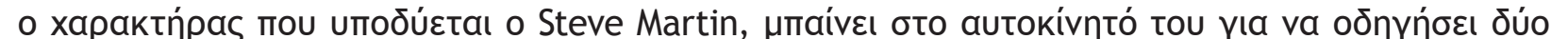

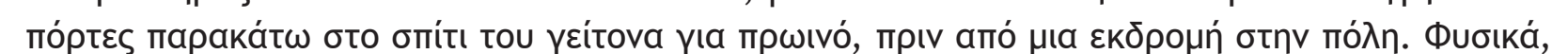

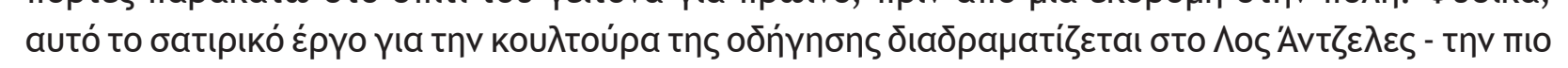

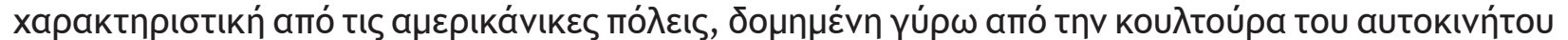

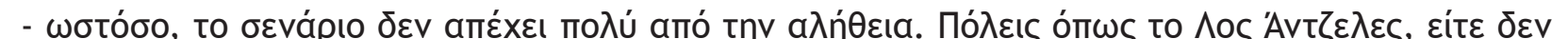

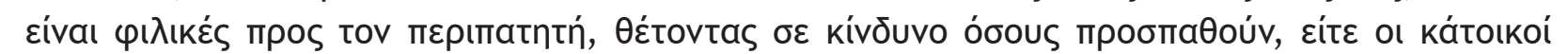

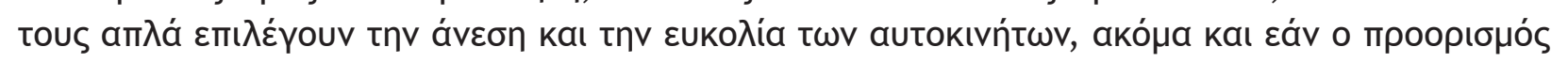

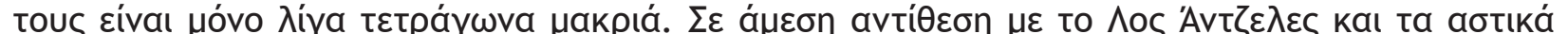

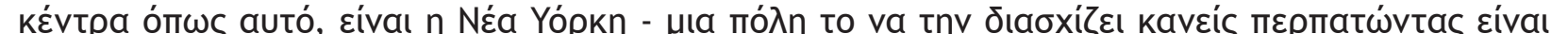

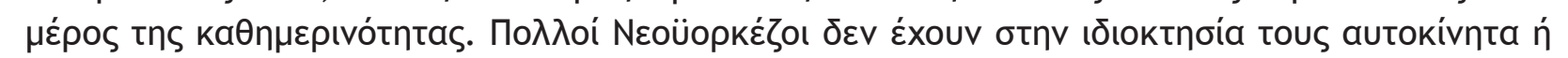

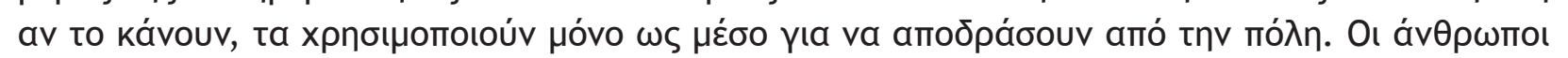

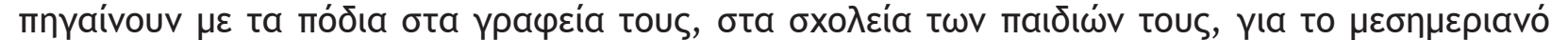

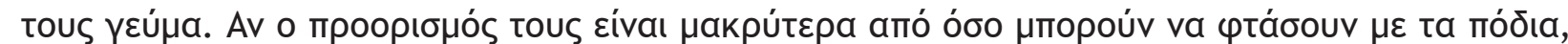

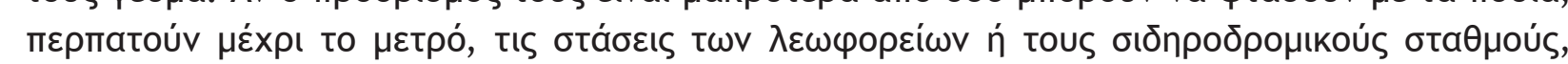

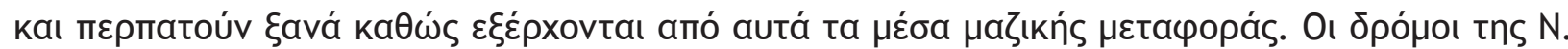

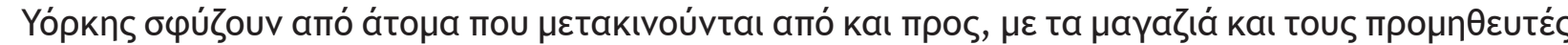

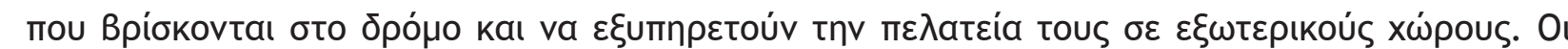

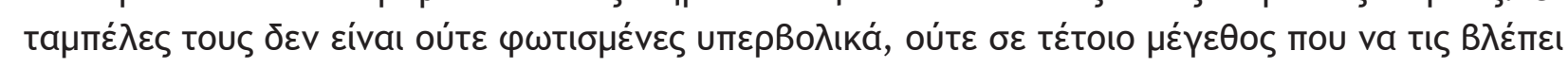

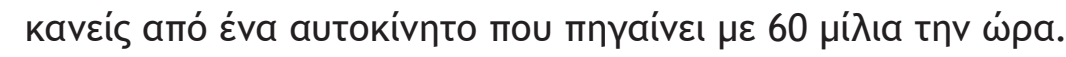

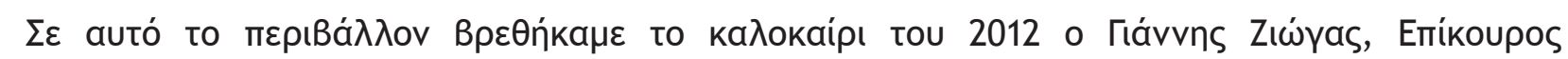




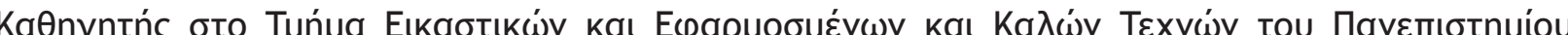

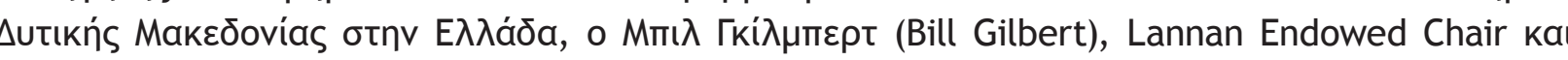

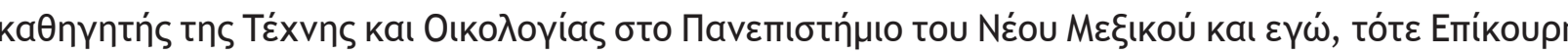

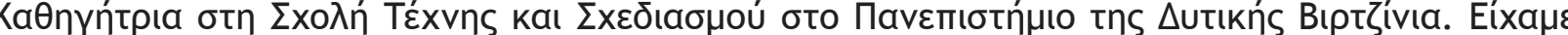

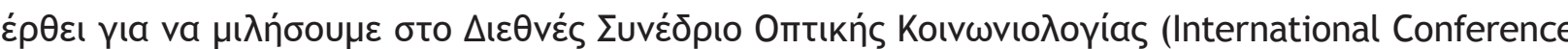

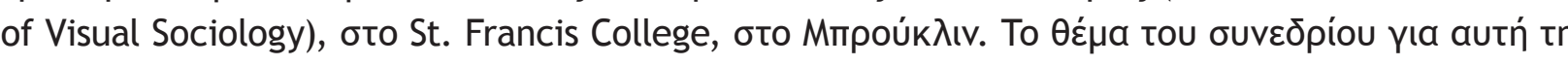

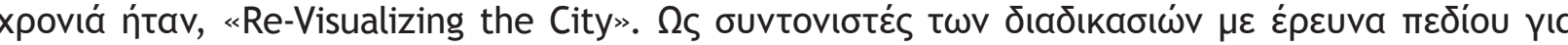

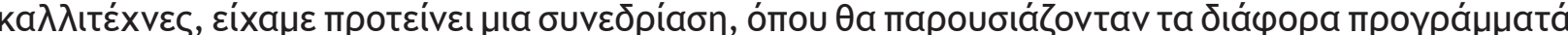

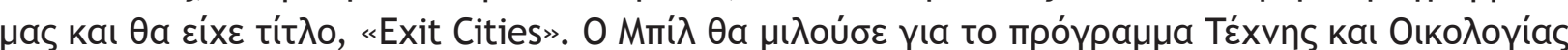

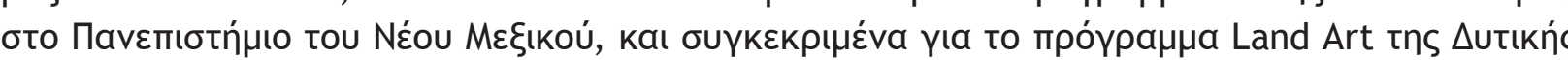

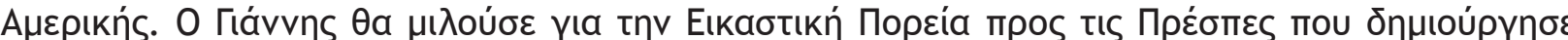

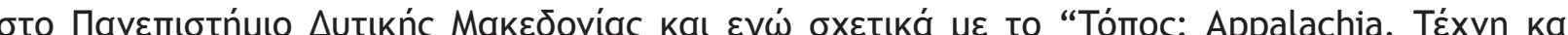

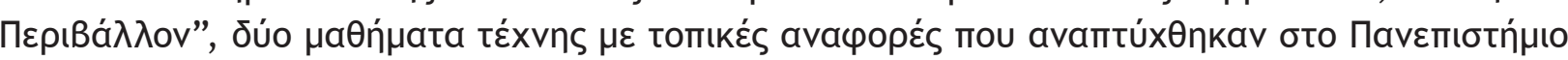

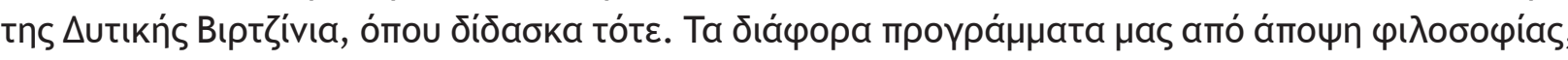

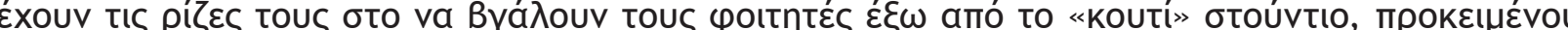

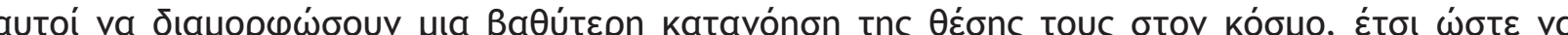

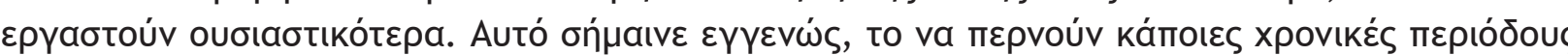

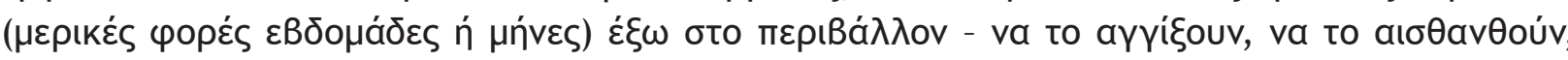

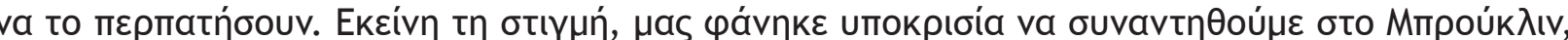

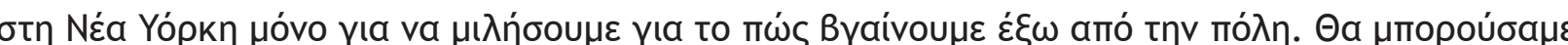

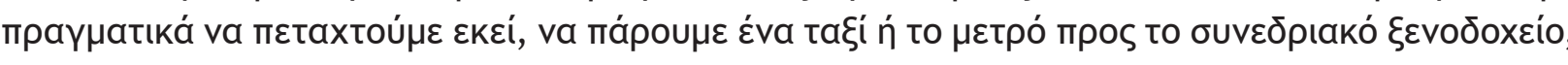

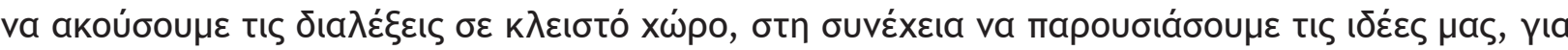

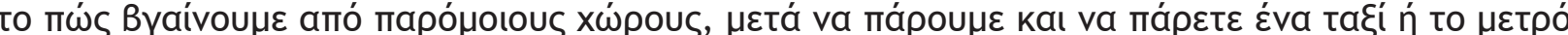

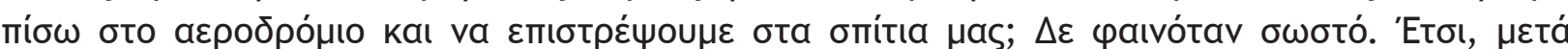

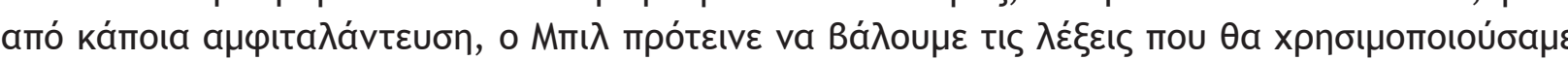

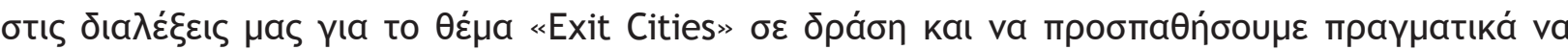

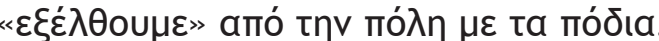

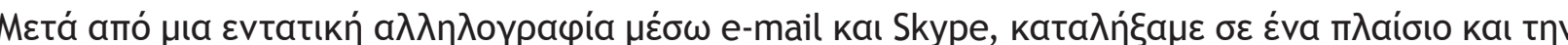

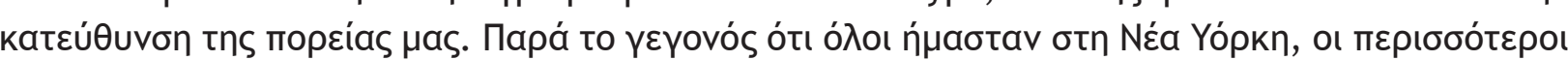

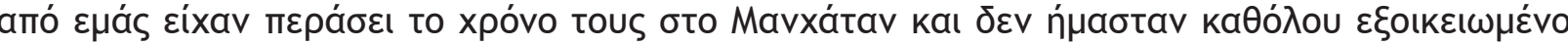

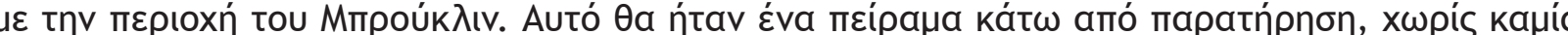

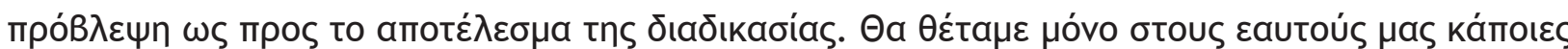
паранर́tрous:

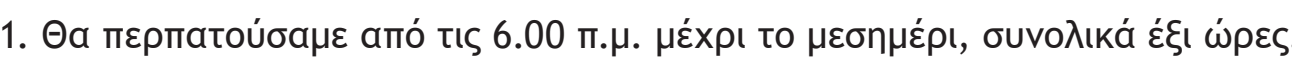

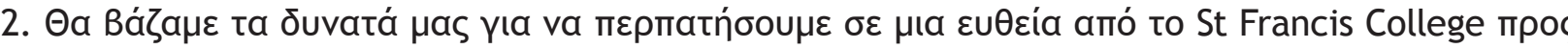

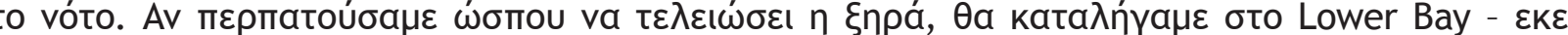

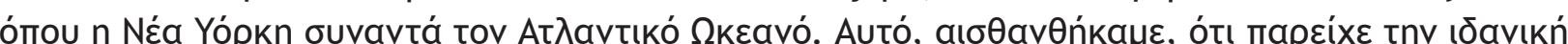

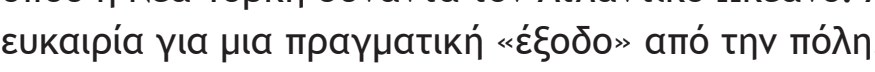

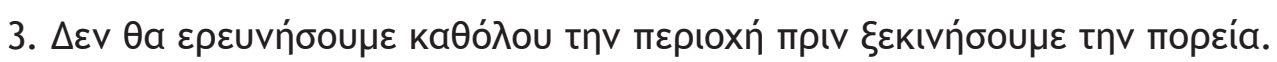

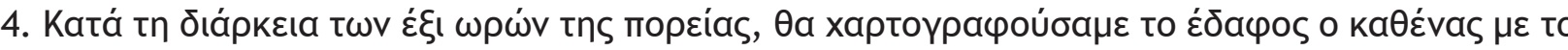

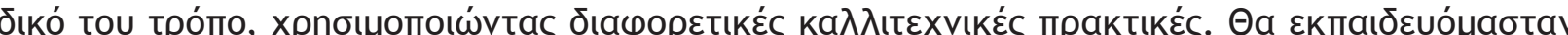

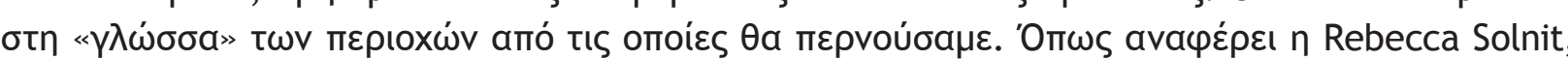

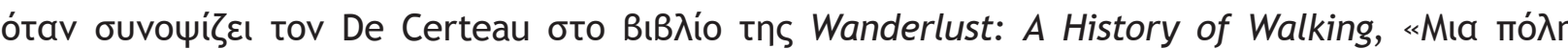

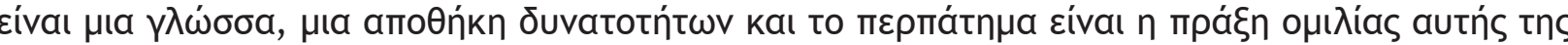

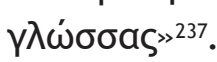

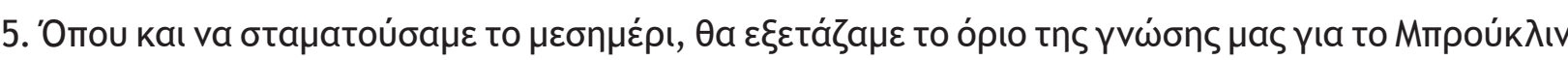

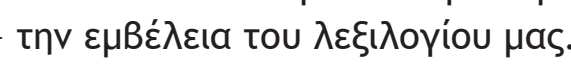

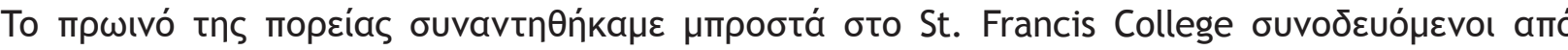

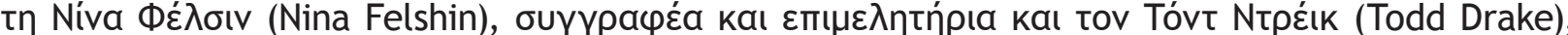

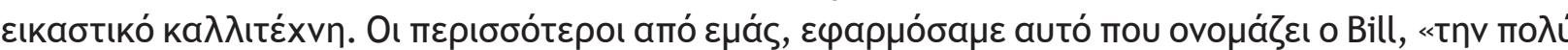

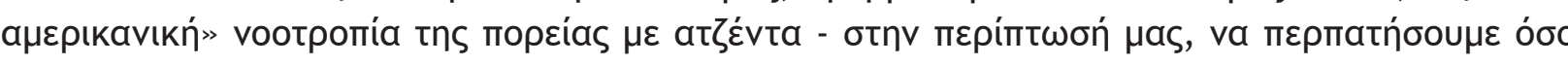

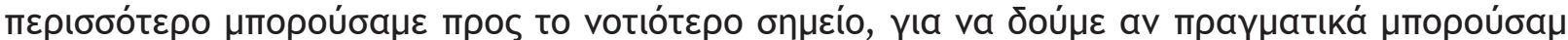

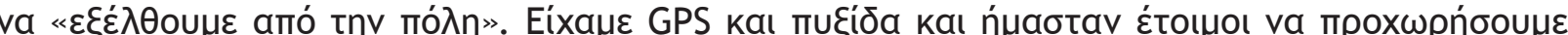

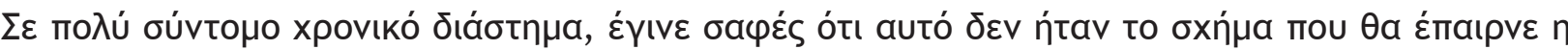

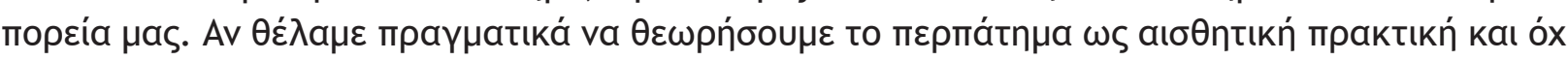

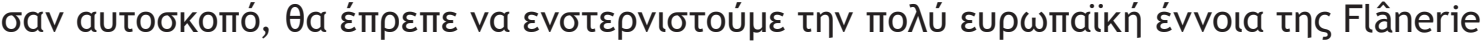

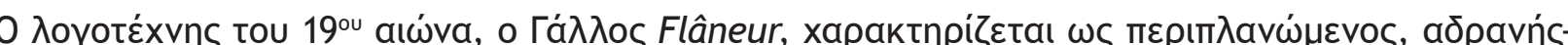

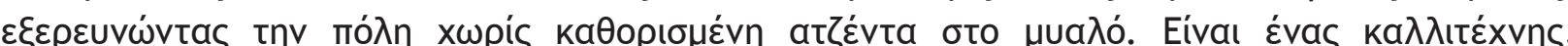

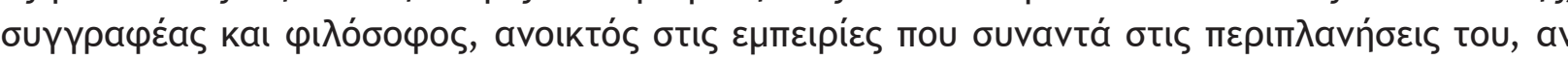

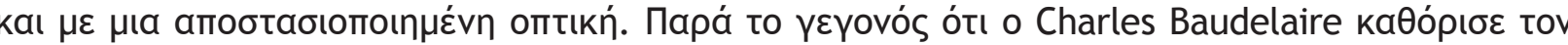

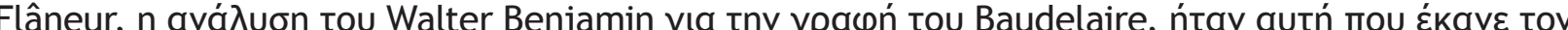

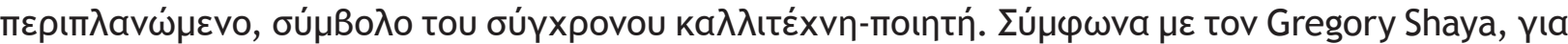

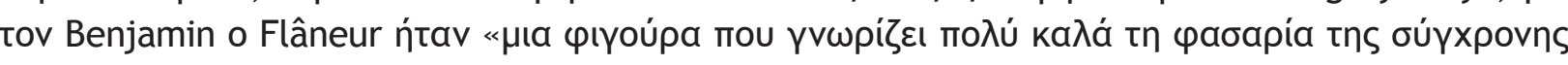

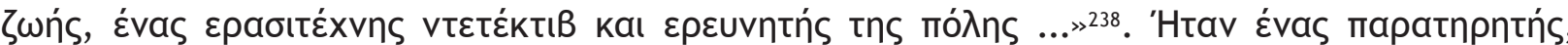

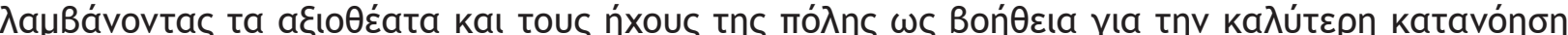

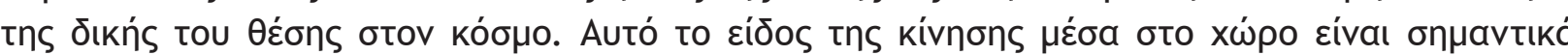

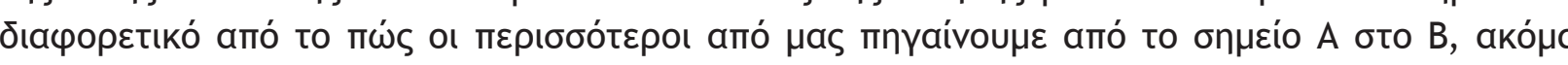
kaı ótav пврпата́

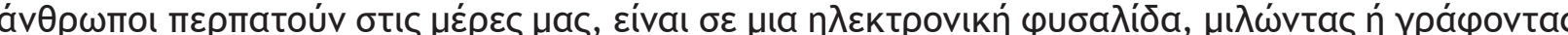

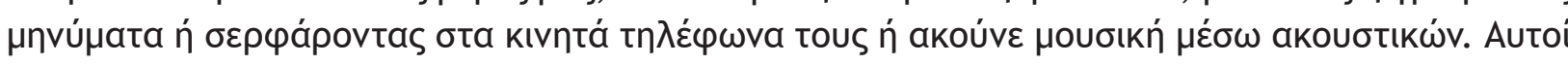

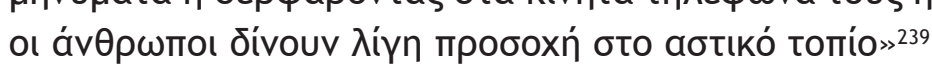

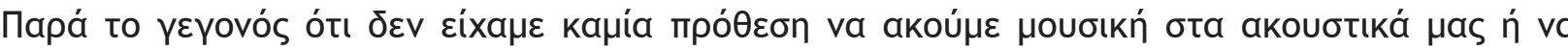

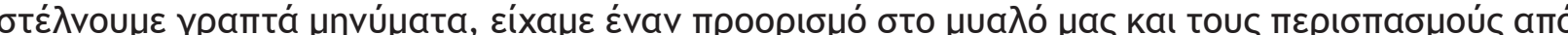

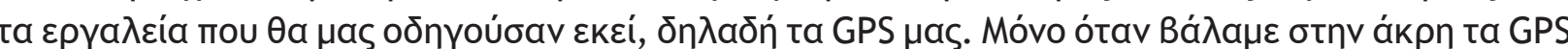

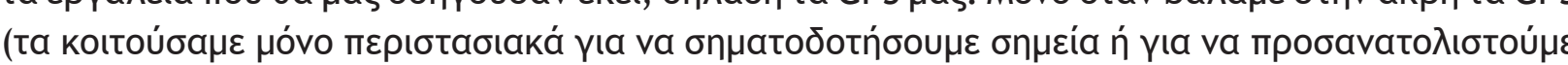

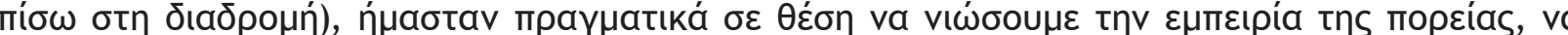

237. Solnit, R. (2000). Wanderlust: A History of Walking. Néa Yópkn: Penguin Books. 213

238. Shaya, G. (2004). The Flaneur, the Badaud, and the Making of a Mass Public in France, circa 1860-1910, The

239. Miller, S. (2015). Walking New York. New York: Fordham University Press, $\sigma \varepsilon \lambda .209$ 


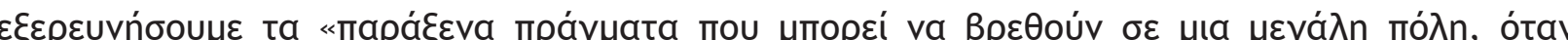

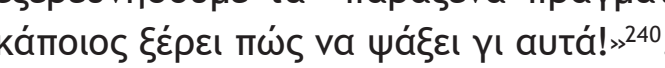

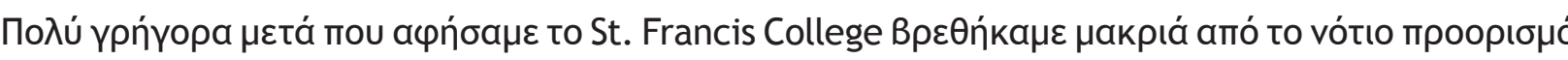

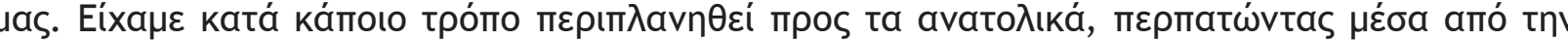

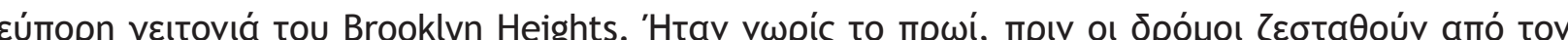

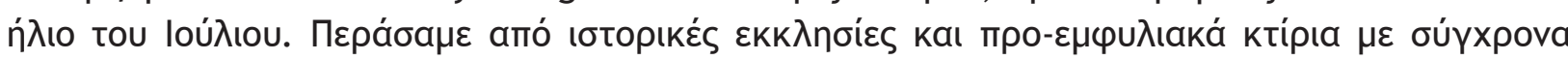

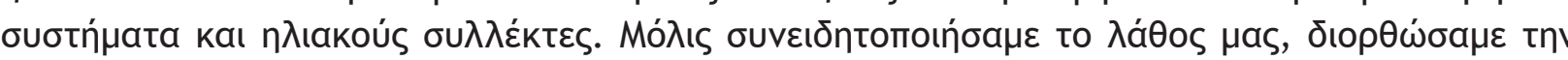

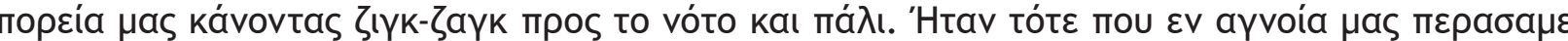

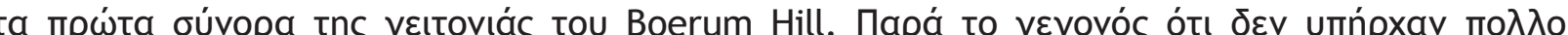

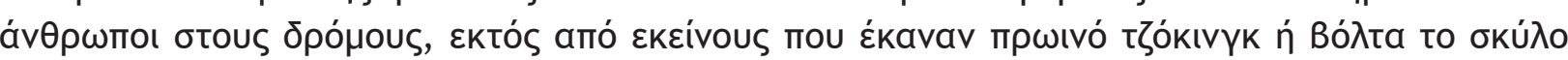

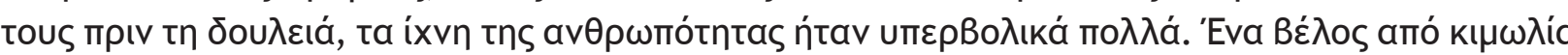

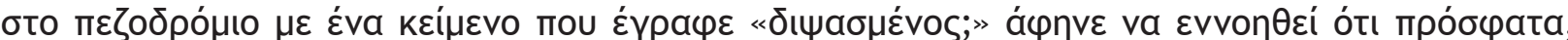

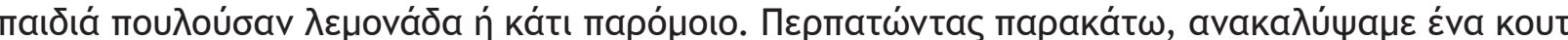

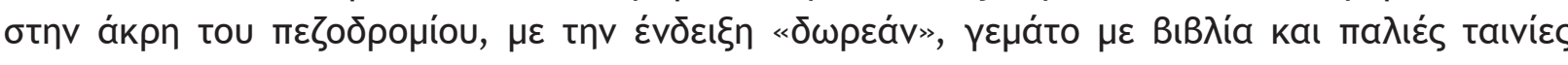

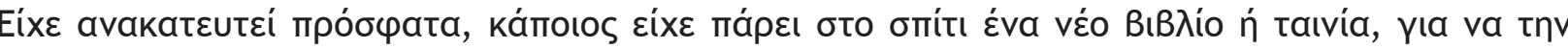

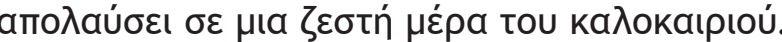

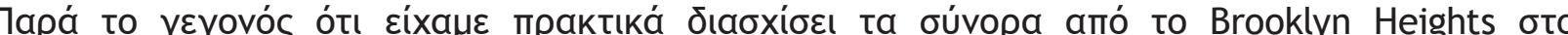

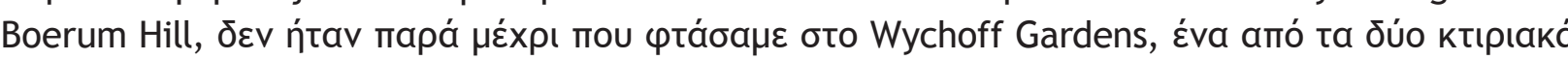

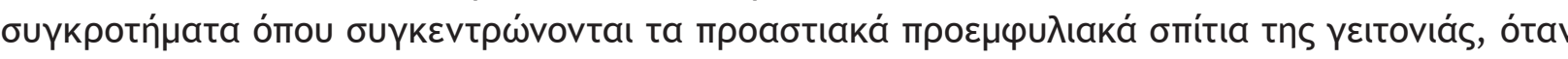

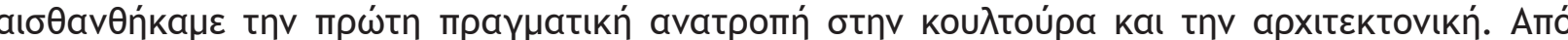

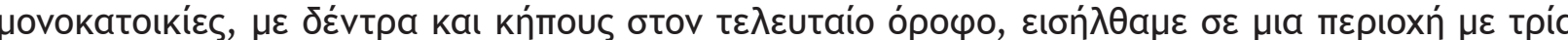

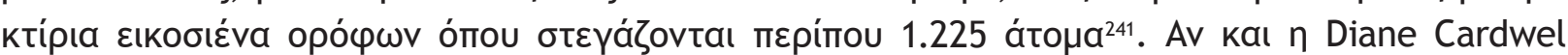
пврıүра́

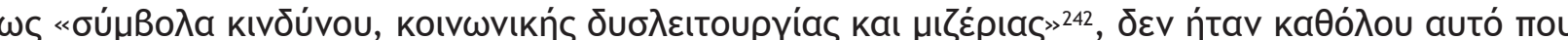

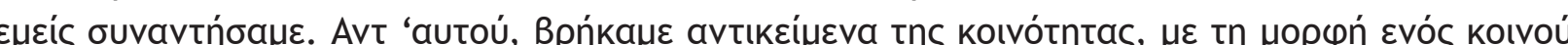

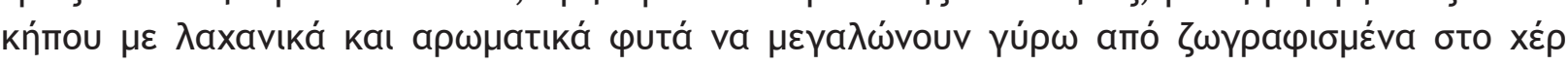

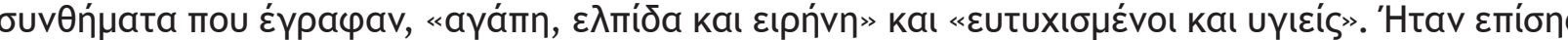

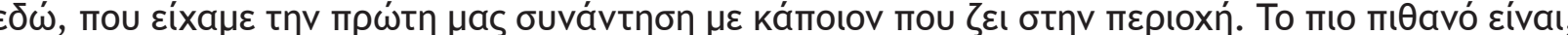

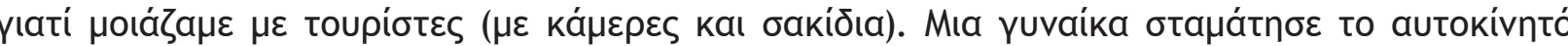

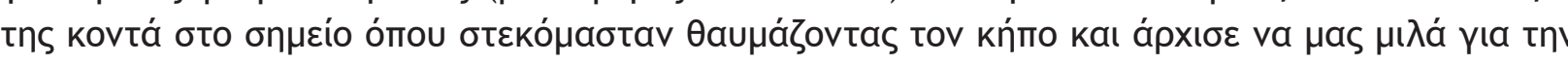

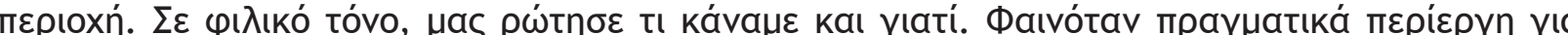

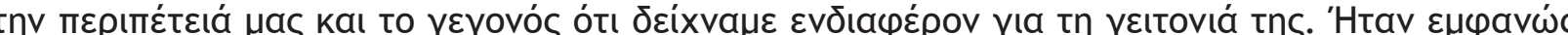

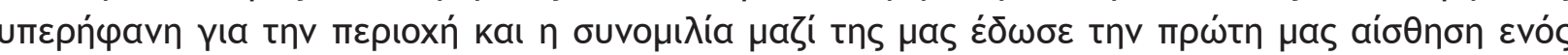

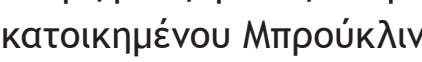

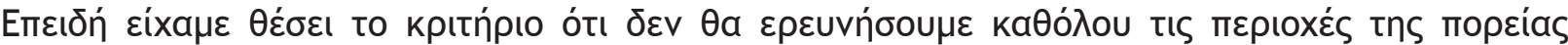

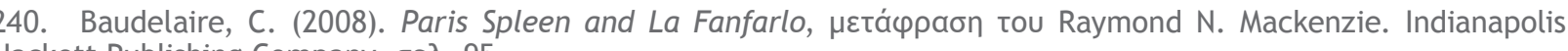

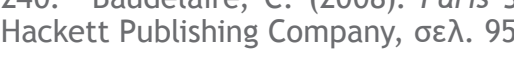

241. NYCHA Housing Developments, New York City Housing Authority, http://www.nyc.gov/html/nycha/htm/

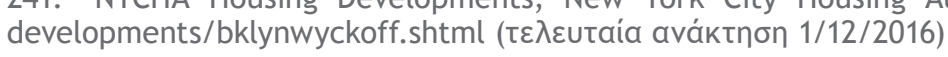

242. Cardwell, D. (2011). In Brooklyn, A Quaint Block and A Symbol of Blight, The New York Times, Oct 24, 2011

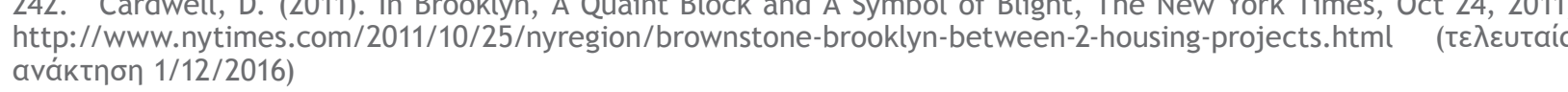

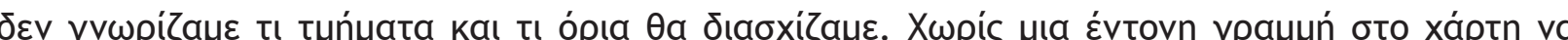

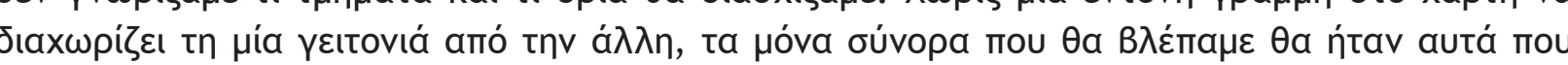

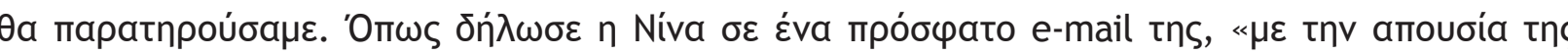

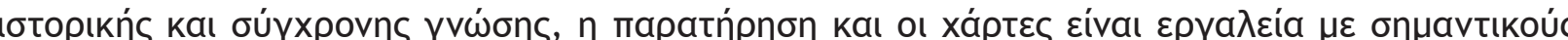

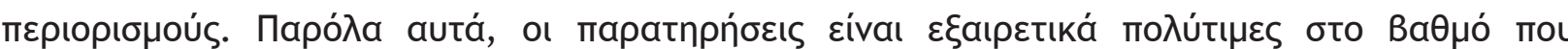

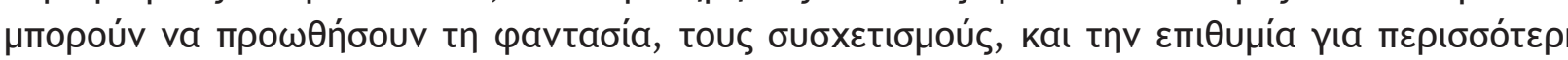

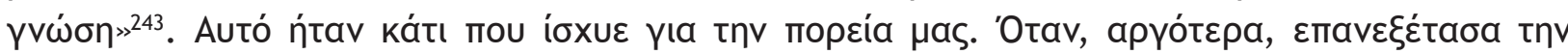

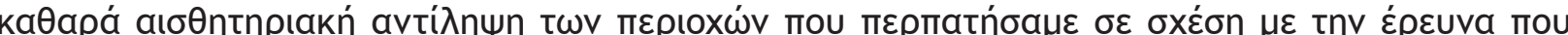

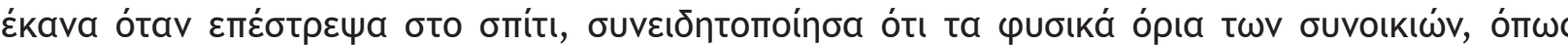

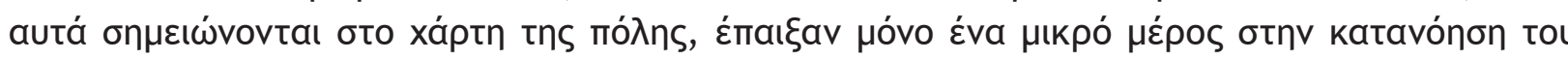

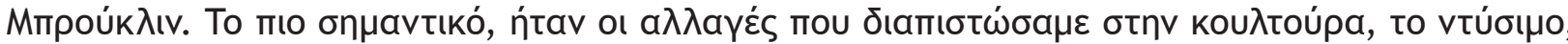

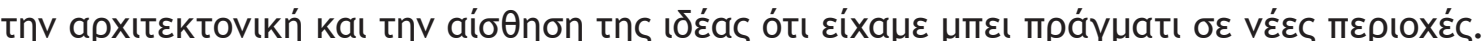

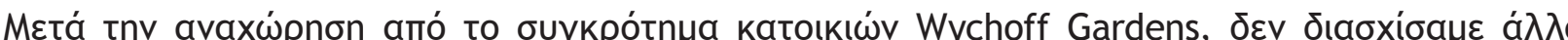

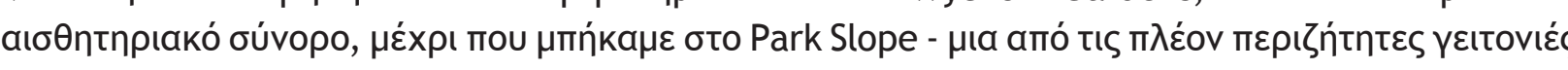

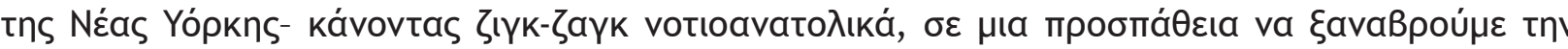

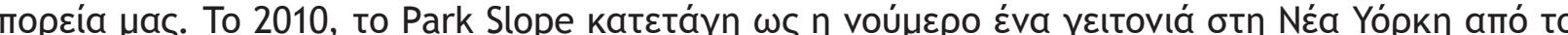

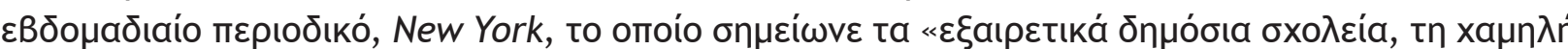

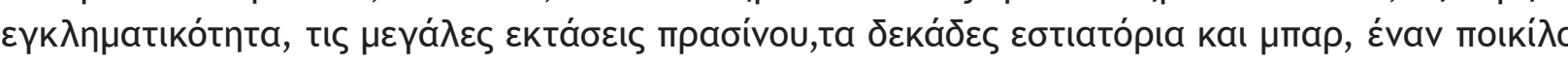

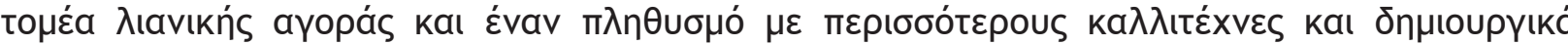

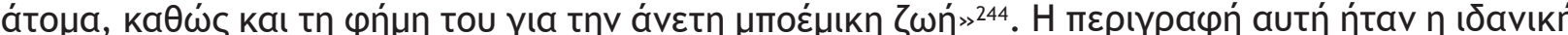

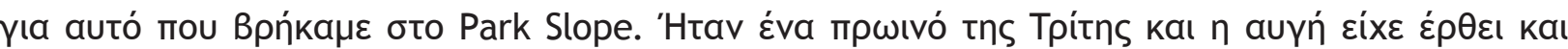

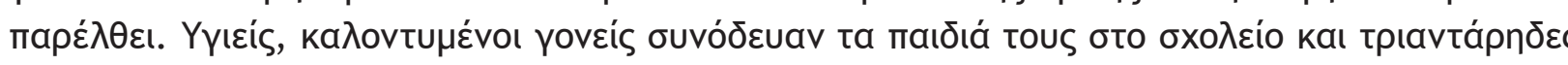

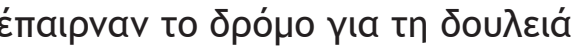

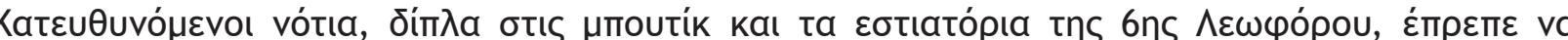

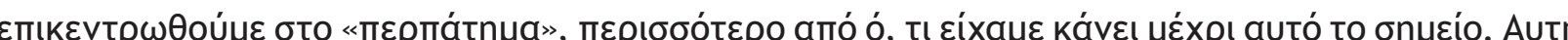

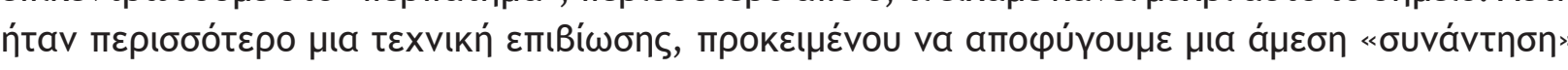

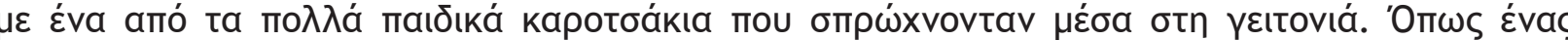

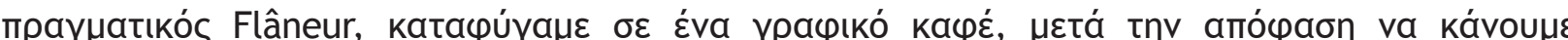

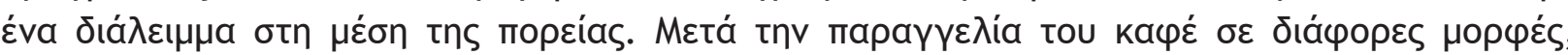

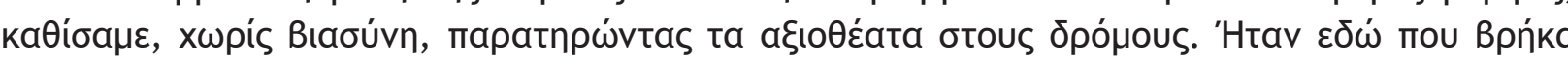

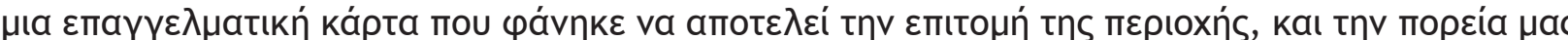

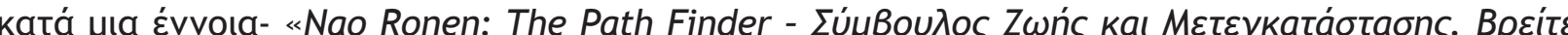

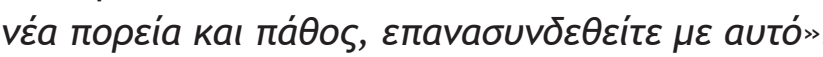

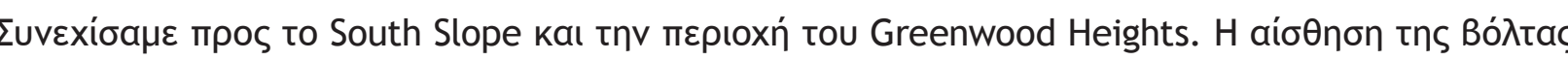

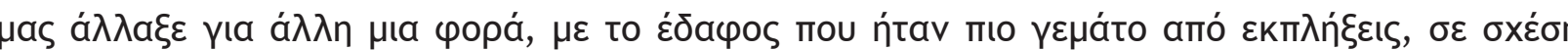

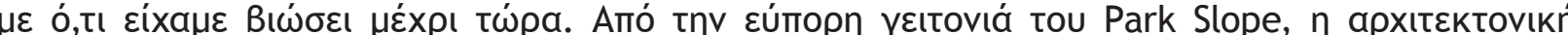

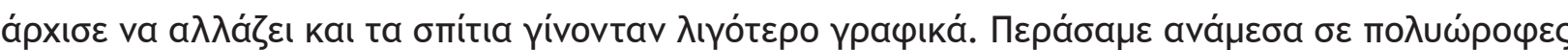

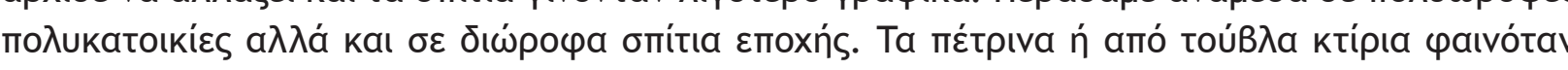

243. Felshin, Nina, e-mail message to author, May 1, 2015

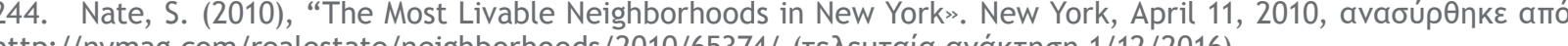

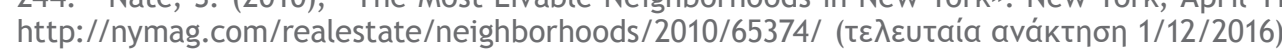




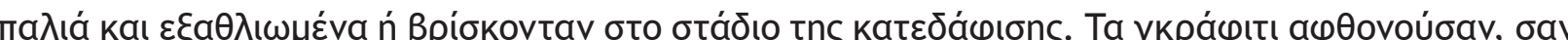

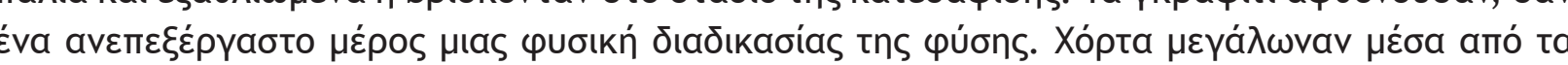

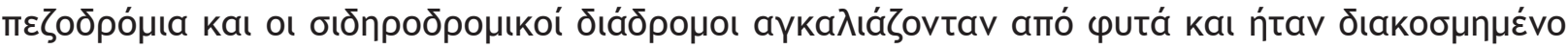

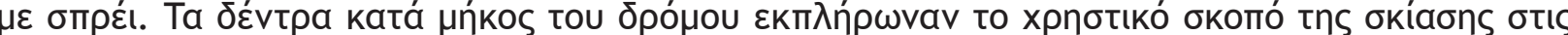

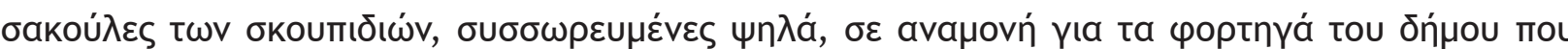

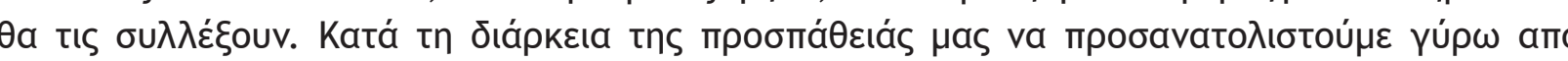

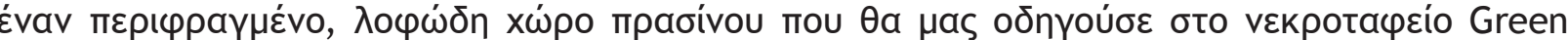

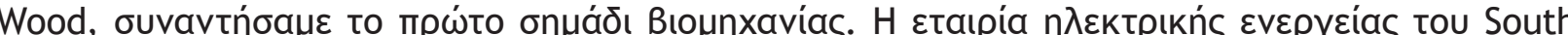

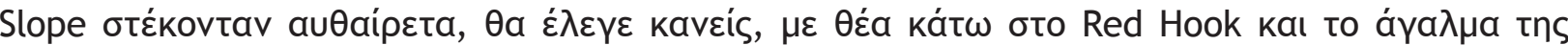

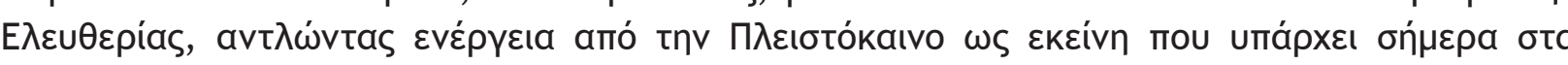

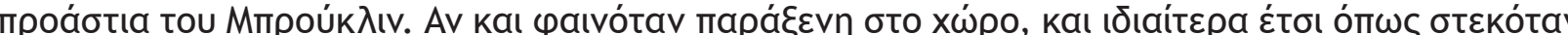

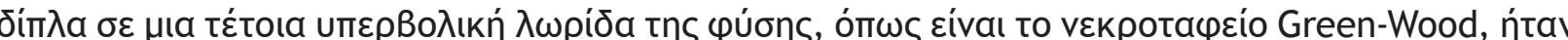

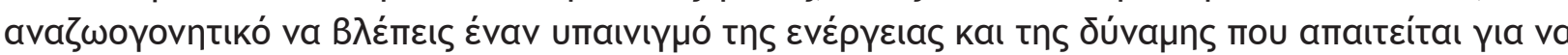

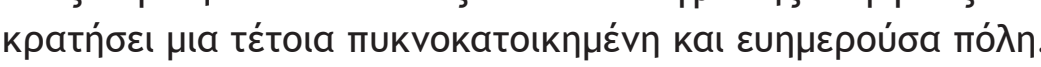

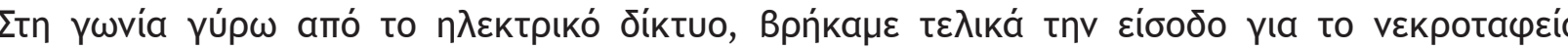

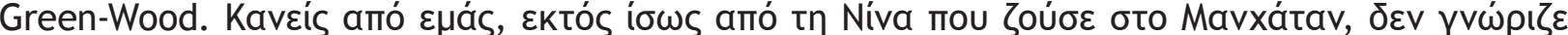

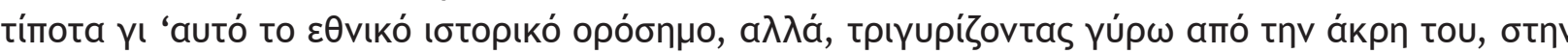

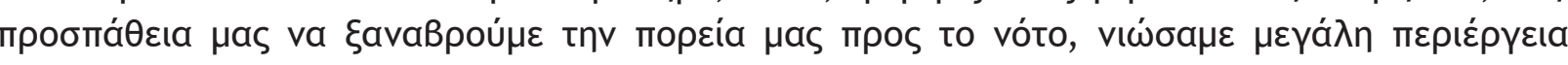

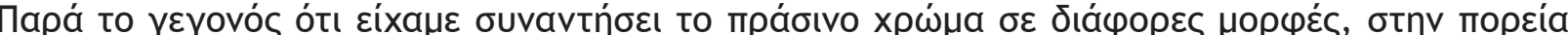

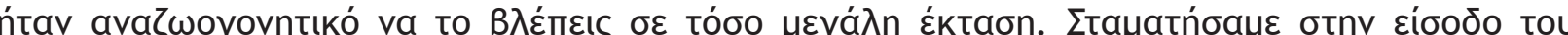

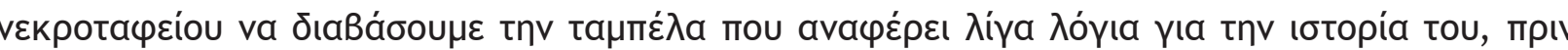

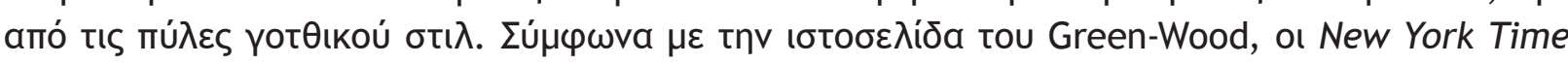

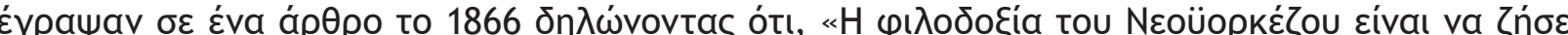

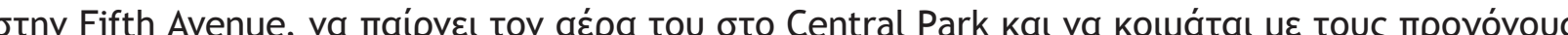

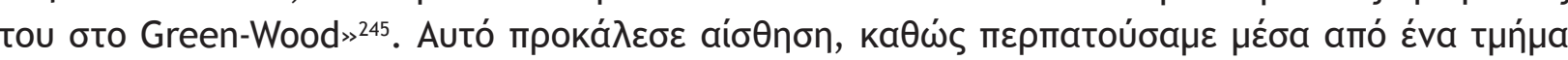

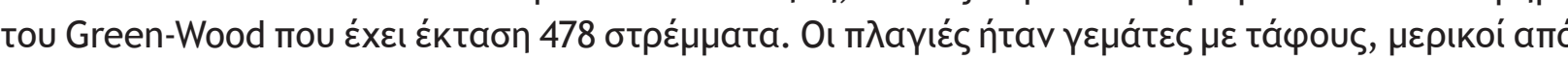
tous omoíous a

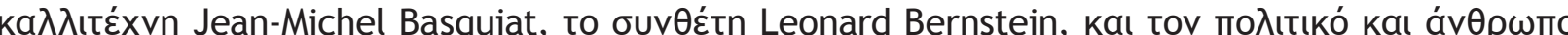

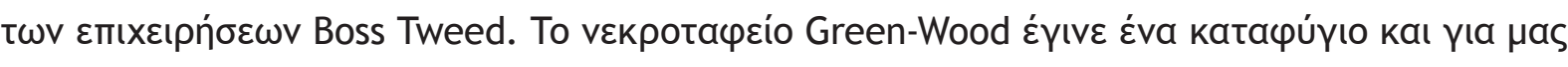

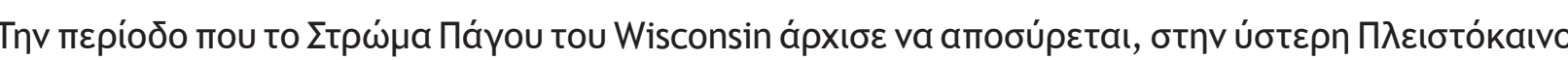

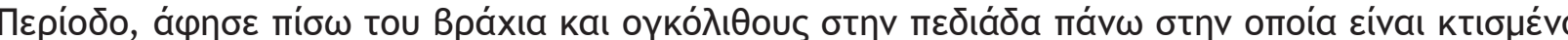

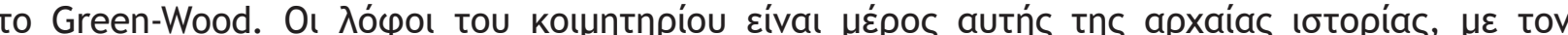

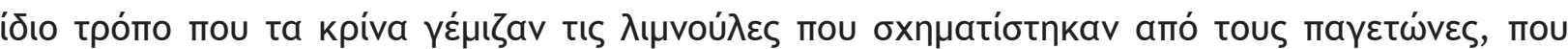
uாńpxav o

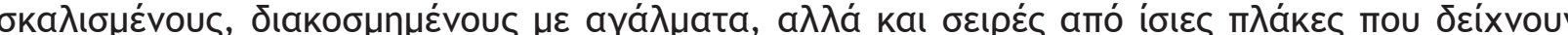

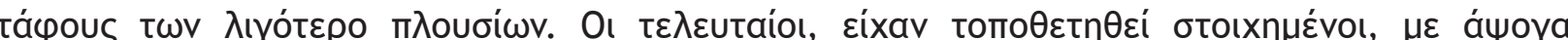

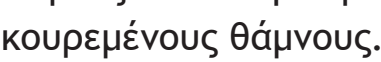

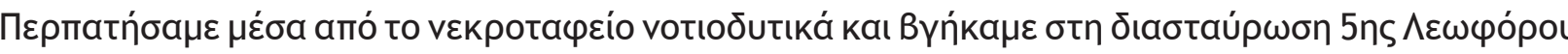

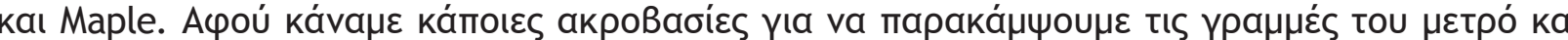

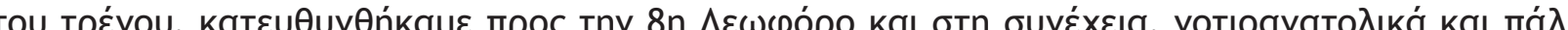

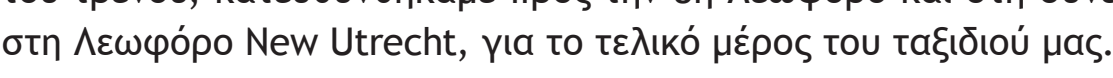

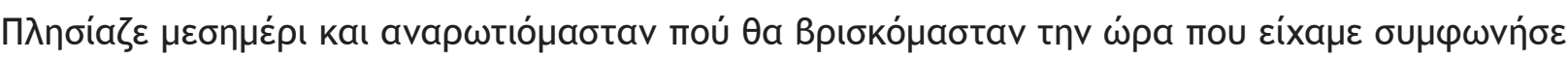

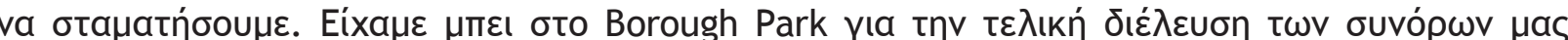

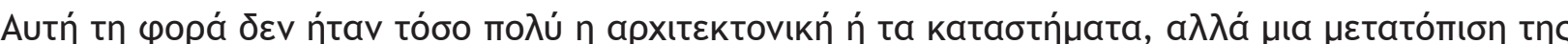

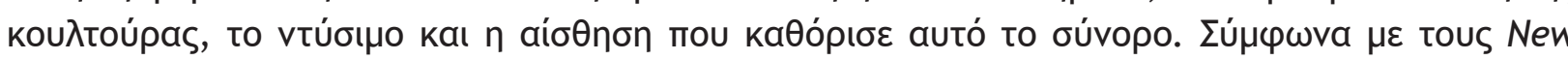

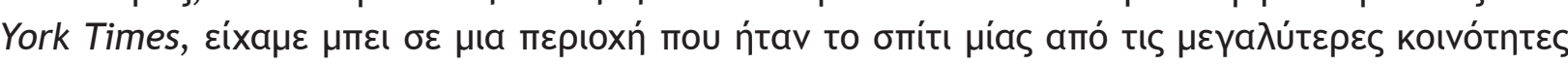

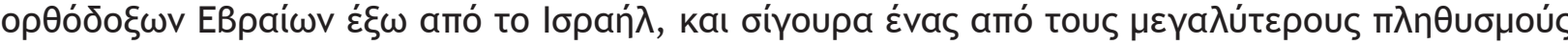

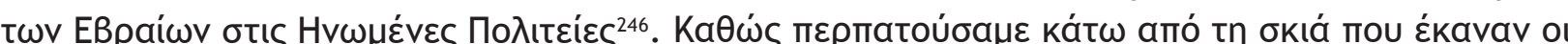

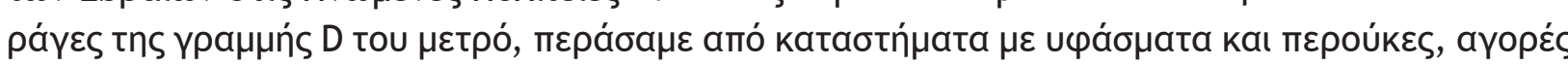

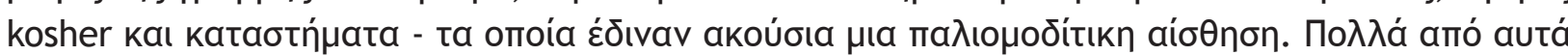

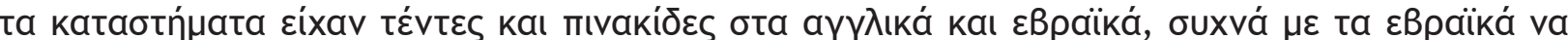

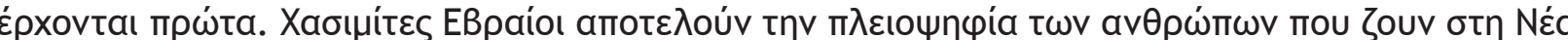

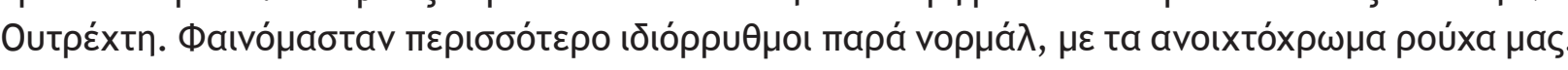

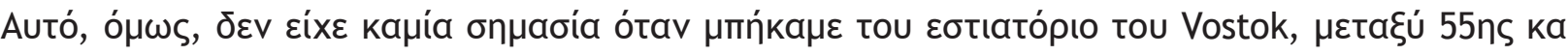

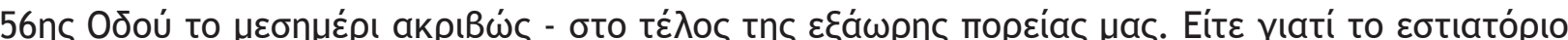

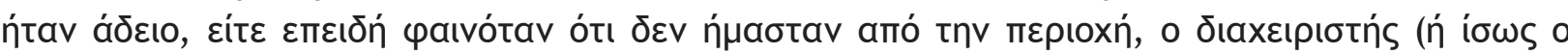

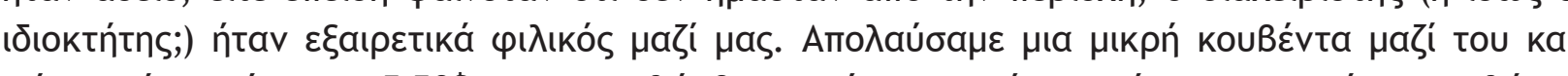

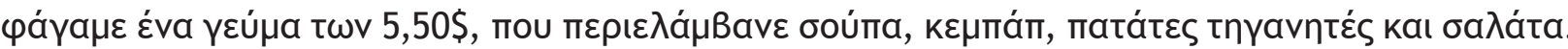

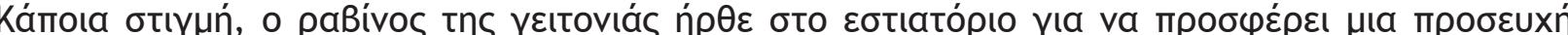

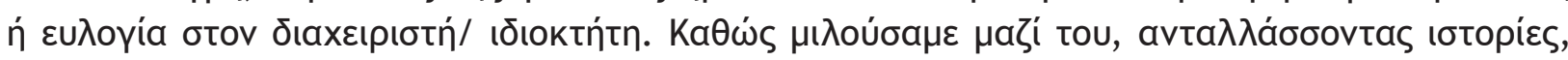

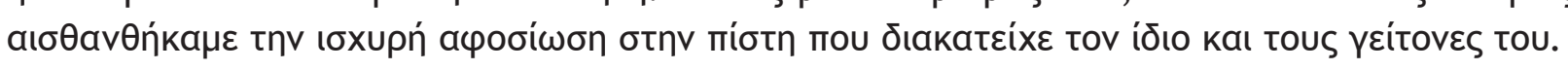

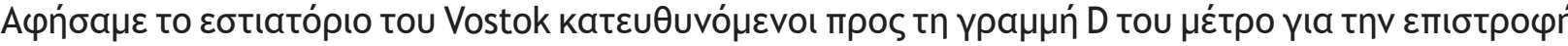

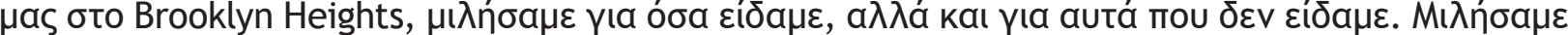

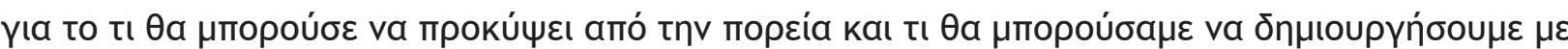

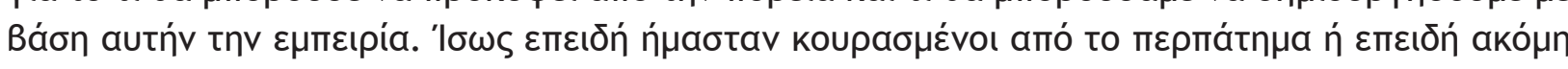

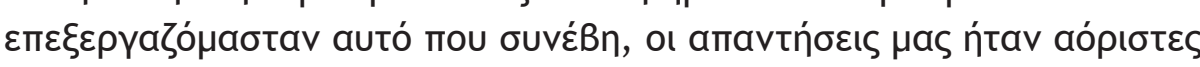

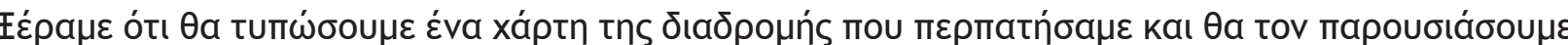

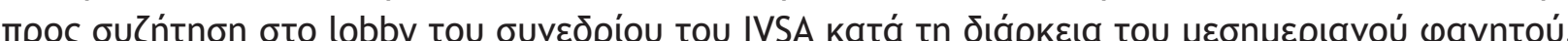

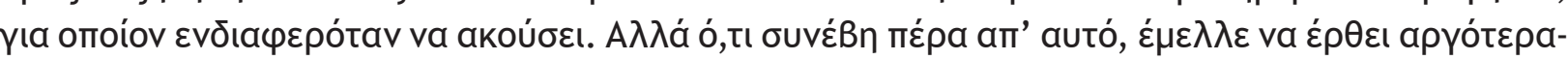

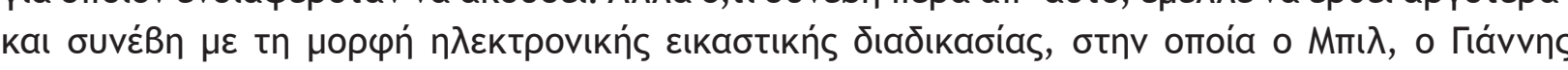

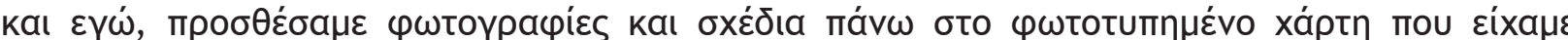

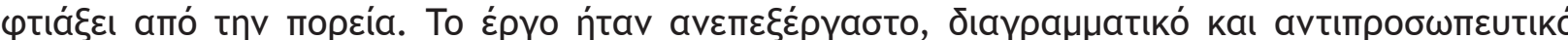

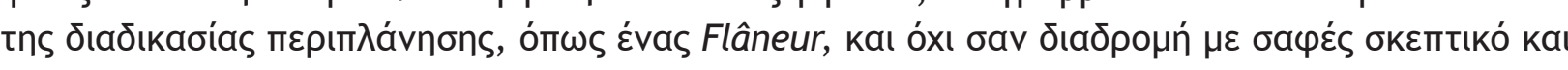

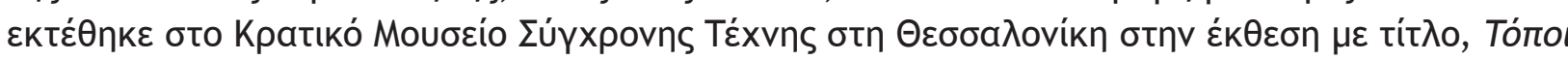

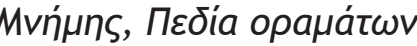

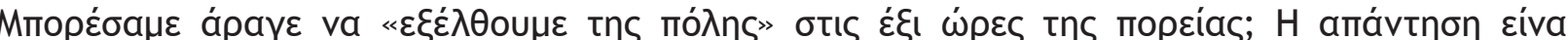

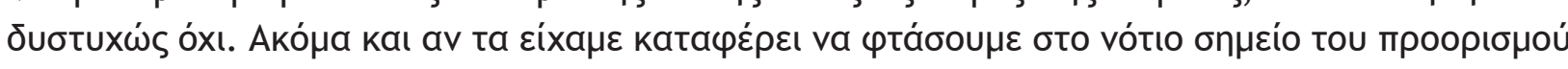

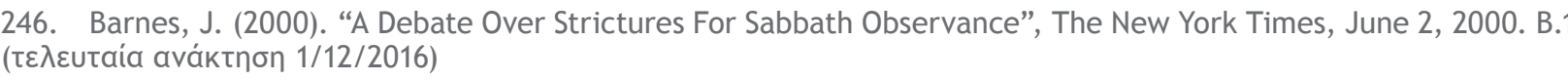




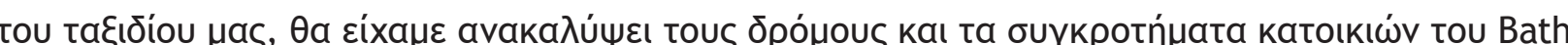

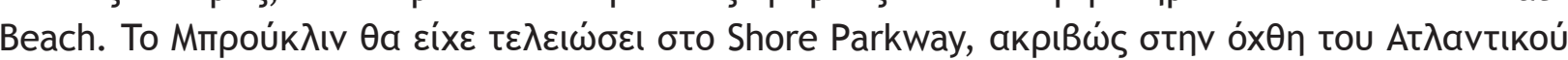

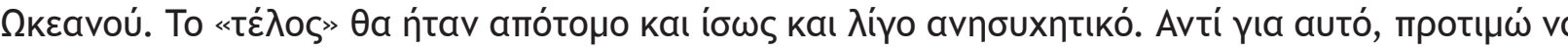

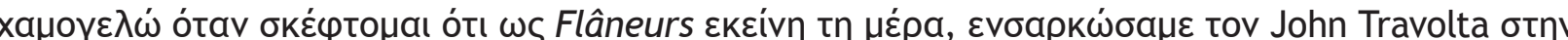

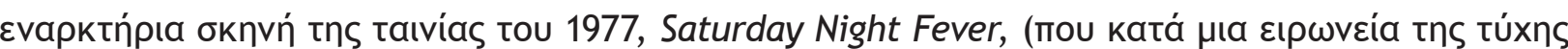

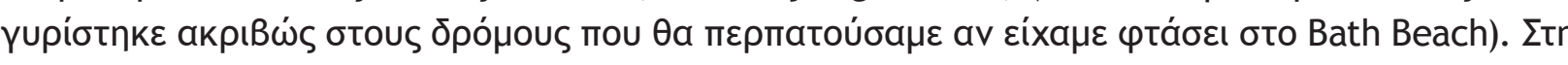

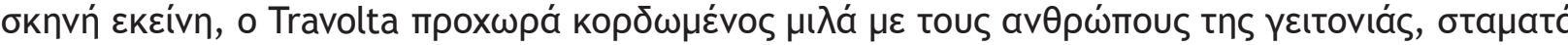

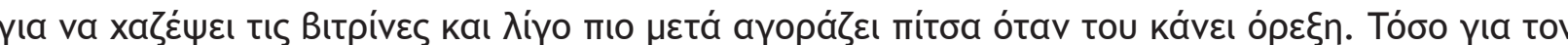

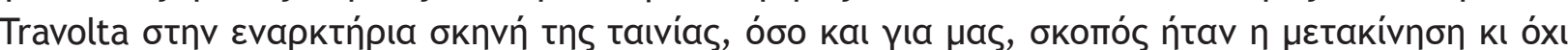
о проopıбнós.

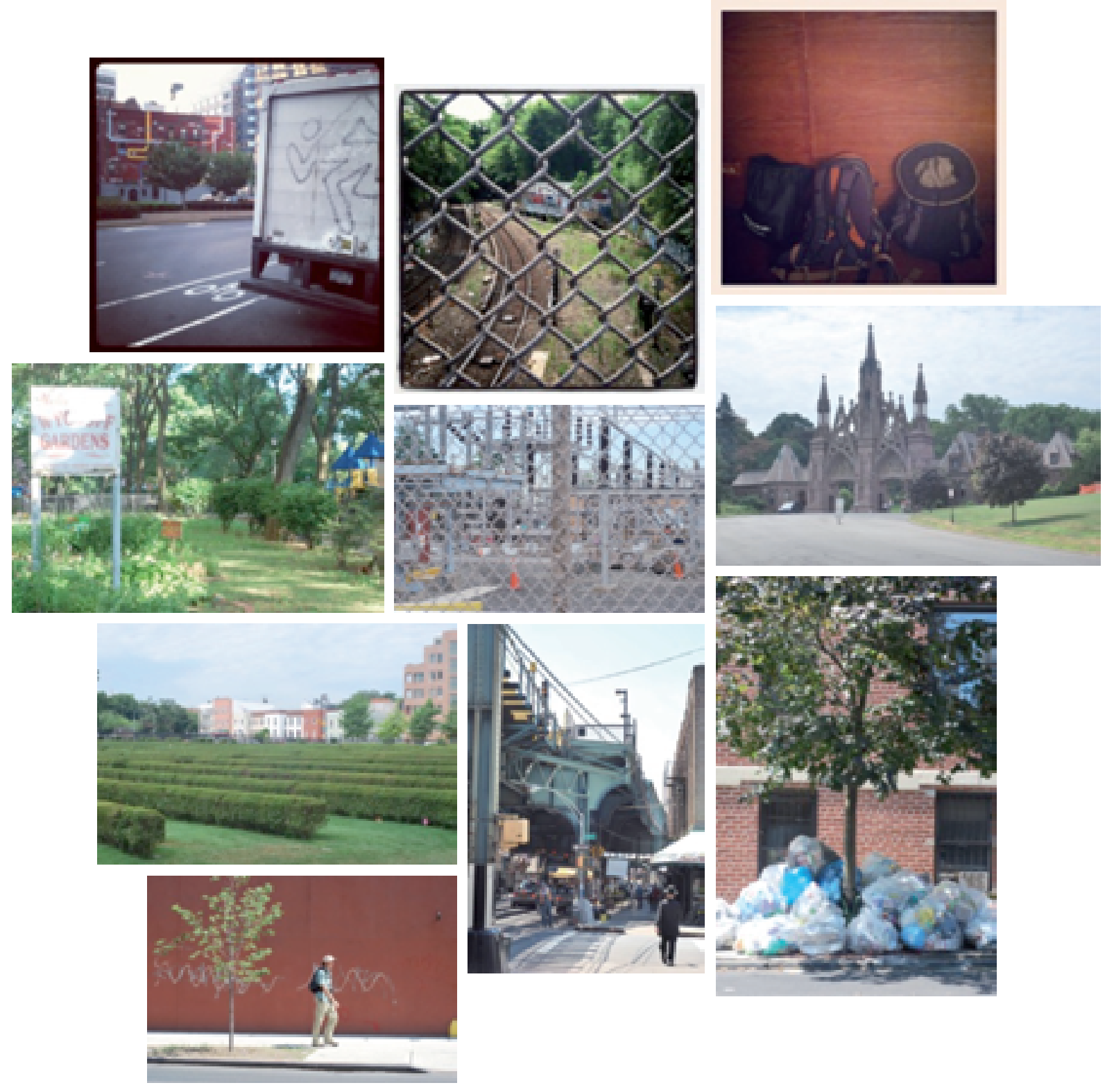

